\title{
These violent repeats have violent extends
}

Julien Couthouis, PhD, and Aaron D. Gitler, PhD

Neurol Genet 2018;4:e247. doi:10.1212/NXG.0000000000000247

Amyotrophic lateral sclerosis (ALS) is a devastating neurodegenerative disease that causes paralysis and death typically within 3 years of onset. The rapidly progressive loss of motor neurons in the brain and spinal cord leads to muscle atrophy, causing weakness, muscle fasciculations, and spasticity. This interferes with normal movement, gait, speech, and swallowing. ALS progresses inexorably, causing paralysis and eventually death. There is currently no cure for ALS and only 2 drugs have been approved, but these only offer limited benefit. More effective therapeutic strategies are desperately needed.

Most ALS cases are sporadic, but around $10 \%$ have a family history. Although these familial cases are rarer than the sporadic ones, they have played an outsize role in contributing to insight into the causes and mechanisms of ALS. This is because these familial cases can be analyzed by genetic approaches to map and sequence genes that cause ALS. The first gene associated with familial ALS was SOD $1 .{ }^{1}$ SOD1 mutations have been found in approximately $20 \%$ of familial cases, which equals approximately $2 \%$ of all ALS cases. It is believed that the ALS-causing mutations in SOD1 lead to a toxic gain of function of the protein. Clinical trials in human patients with ALS are currently under way to test the efficacy of an SOD1-lowering therapy, using antisense oligonucleotides. ${ }^{2}$ Although SOD 1 mutations in ALS are relatively rare, the path from $S O D 1$ gene discovery to targeted therapy illustrates the power of genetics in illuminating the causes of ALS, paving the path for the development of novel therapies. Owing to the explosion in new gene sequencing technologies, the number of ALS genes has been increasing exponentially ${ }^{1}$ - each new gene offering the hope for a better understanding of ALS mechanisms. The identification of causative genes for ALS will also improve early diagnosis, which will undoubtedly give therapies a better shot at success.

One of these newly discovered genes is now the most common genetic cause of ALS. Discovered in 2011, mutations in the C9ORF72 gene cause $\sim 40 \%$ of familial ALS cases and $\sim 10 \%$ of sporadic cases. ${ }^{1}$ The ALS-causing mutation in C9ORF72 is a hexanucleotide repeat expansion located in a noncoding portion of the gene. Normally, the gene harbors only a handful of GGGGCC repeats, but in individuals with C9ORF72 mutations, the number of repeats increases to hundreds or even thousands. Intense research efforts are under way to define how these violent nucleotide repeat expansions in C9ORF72 cause ALS and to devise therapeutic strategies. Of interest, the repeat expansion in C9ORF72 can be traced back to a single founding event, probably in Northern Europe. ${ }^{3}$ Despite being common in Europe and North America, it is extremely rare in Asian ALS populations. ${ }^{4}$ The paucity of C9ORF72 mutations in Asia raises the question of whether repeat expansions in other genes could be more common causes of ALS in this population.

Beyond C9ORF72, repeat expansions in at least 2 other genes, NOP56 and ATXN2, have been associated with motor neuron disease, including ALS. ${ }^{5,6}$ Noncoding GGCCTG-repeat expansions in the NOP56 gene cause spinocerebellar ataxia type 36, which can present with prominent motor neuron degeneration. Long trinucleotide CAG-repeat expansions in the ATXN2 gene cause spinocerebellar ataxia type 2 (SCA2). Of interest, intermediate-length CAG repeat expansions in the same gene are associated with ALS. ${ }^{6}$ Therapeutic strategies to target ATXN2 are being pursued for SCA2 and ALS. ${ }^{7,8}$
Correspondence

Dr. Gitler

agitler@stanford.edu

\section{RELATED ARTICLE}

Noncoding repeat expansions for ALS in Japan are associated with the ATXN8OS gene

Page e252 
In this issue of Neurology ${ }^{\circledR}$ Genetics, Hirano et al. ${ }^{9}$ analyzed the length of the repeat expansion in 3 genes, ATXN8OS, C9ORF72 and NOP56, in 103 Japanese patients with ALS. In this cohort, 3 patients harbored a pathologic expansion in the ATXN8OS gene. Although healthy controls harbored between 15 and 50 CTA/CTG repeats, patients with ALS had more than 80 repeats. Since the authors found ATXN8OS repeat expansions in $3 \%$ of patients with ALS, it suggests that such mutations may be relatively common in Japan.

Nucleotide repeat expansions in ATXN8OS have been previously connected with another neurodegenerative disease, spinocerebellar ataxia type 8 (SCA8). SCA8 is a slowly progressive ataxia with disease onset from age 1 to the early $70 \mathrm{~s}$ but typically with an adult onset. ${ }^{10}$ As opposed to the rapid progression observed in ALS, SCA8 progression is slow and spans decades, regardless of the initial age at onset; lifespan is typically not shortened. Initial symptoms are scanning dysarthria with a characteristic drawn-out slowness of speech and gait instability. Various atypical clinical features have also been identified in patients carrying an ATXN8OS expansion, such as parkinsonism, multiple-system atrophy, severe childhood onset, oromandibular dystonia, dysphagia, respiratory muscle weakness, or seizure-like episodes.

The next steps are to extend the analysis of ATXN8OS in a larger Japanese ALS population to confirm these exciting findings and to also test other Asian ALS patient populations (e.g., China and Korea). It will also be important to carefully re-evaluate SCA8 cases and pedigrees to define the prevalence of symptoms warranting a diagnosis of ALS. Looking to the mechanism, future studies should focus on how the ATXN8OS repeat expansions cause pathologies and how such pathologies contribute to motor neuron degeneration.

The work of Hirano et al. is especially interesting in a clinical diagnostic standpoint. We now see a significant genetic overlap between neurodegenerative diseases such as spinocerebellar ataxia, hereditary spastic paraplegia, ALS, and frontotemporal dementia. It is still unclear whether the clinical manifestations of these mutations result from different pathologic mechanisms, different affected cell types, or different genetic backgrounds harboring a diverse set of genetic modifier genes. It may be beneficial to start developing and implementing broad multigene test panels for neurodegenerative and neuromuscular diseases, as is standard practice in cancer screening.

\section{Study funding}

No targeted funding reported.

\section{Disclosure}

J. Couthouis has received research support from Target ALS. A.D. Gitler has been a consultant for Aquinnah Pharmaceuticals, Prevail Therapeutics, and Third Rock Ventures and has received research support from the NIH. Full disclosure form information provided by the authors is available with the full text of this article at Neurology.org/NG.

\section{References}

1. Brown RH Jr, Al-Chalabi A. Amyotrophic lateral sclerosis. N Engl J Med 2017;377: 1602.

2. Miller TM, Pestronk A, David W, et al. An antisense oligonucleotide against SOD 1 delivered intrathecally for patients with SOD 1 familial amyotrophic lateral sclerosis: a phase 1, randomised, first-in-man study. Lancet Neurol 2013;12: $435-442$.

3. Smith BN, Newhouse S, Shatunov A, et al. The C9ORF72 expansion mutation is a common cause of ALS+/-FTD in Europe and has a single founder. Eur J Hum Genet 2013;21:102-108.

4. Chen Y, Lin Z, Chen X, et al. Large C9orf72 repeat expansions are seen in Chinese patients with sporadic amyotrophic lateral sclerosis. Neurobiol Aging 2016;38: 217.e215-217.e222.

5. Miyazaki K, Yamashita T, Morimoto N, et al. Early and selective reduction of NOP56 (Asidan) and RNA processing proteins in the motor neuron of ALS model mice. Neurol Res 2013;35:744-754.

6. Elden AC, Kim HJ, Hart MP, et al. Ataxin-2 intermediate-length polyglutamine expansions are associated with increased risk for ALS. Nature 2010;466:1069-1075.

7. Becker LA, Huang B, Bieri G, et al. Therapeutic reduction of ataxin-2 extends lifespan and reduces pathology in TDP-43 mice. Nature 2017;544:367-371.

8. Scoles DR, Meera P, Schneider MD, et al. Antisense oligonucleotide therapy for spinocerebellar ataxia type 2. Nature 2017;544:362-366.

9. Hirano M. Noncoding repeat expansions for ALS in Japan are associated with the ATXN8OS gene. Neurol Genet 2018;4:e252.

10. Ikeda Y, Shizuka M, Watanabe M, Okamoto K, Shoji M. Molecular and clinical analyses of spinocerebellar ataxia type 8 in Japan. Neurology 2000;54:950-955. 


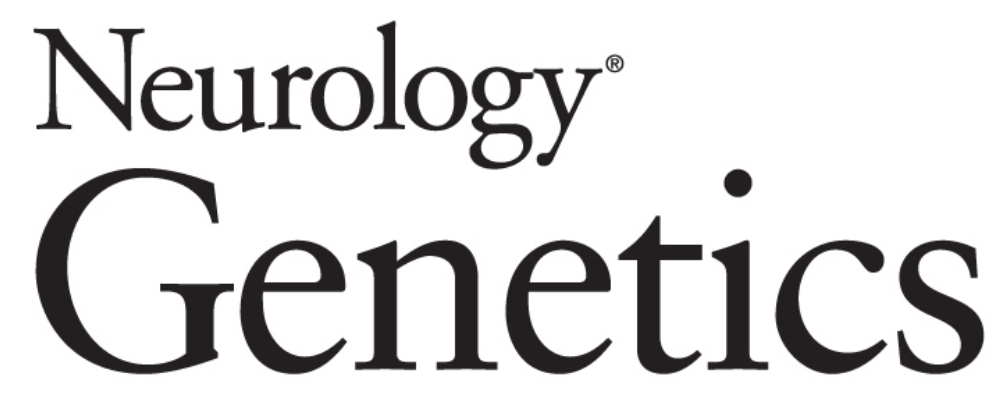

\author{
These violent repeats have violent extends \\ Julien Couthouis and Aaron D. Gitler \\ Neurol Genet 2018;4; \\ DOI 10.1212/NXG.0000000000000247
}

This information is current as of August 1, 2018

\section{Updated Information \& Services}

References

Subspecialty Collections

Permissions \& Licensing

Reprints including high resolution figures, can be found at: http://ng.neurology.org/content/4/4/e247.full.html

This article cites 10 articles, 1 of which you can access for free at: http://ng.neurology.org/content/4/4/e247.full.html\#\#ref-list-1

This article, along with others on similar topics, appears in the following collection(s):

Amyotrophic lateral sclerosis

http://ng.neurology.org//cgi/collection/amyotrophic_lateral_sclerosis_ Spinocerebellar ataxia

http://ng.neurology.org//cgi/collection/spinocerebellar_ataxia

Information about reproducing this article in parts (figures,tables) or in its entirety can be found online at:

http://ng.neurology.org/misc/about.xhtml\#permissions

Information about ordering reprints can be found online: http://ng.neurology.org/misc/addir.xhtml\#reprintsus

Neurol Genet is an official journal of the American Academy of Neurology. Published since April 2015, it is an open-access, online-only, continuous publication journal. Copyright Copyright $\odot 2018$ The Author(s). Published by Wolters Kluwer Health, Inc. on behalf of the American Academy of Neurology.. All rights reserved. Online ISSN: 2376-7839.

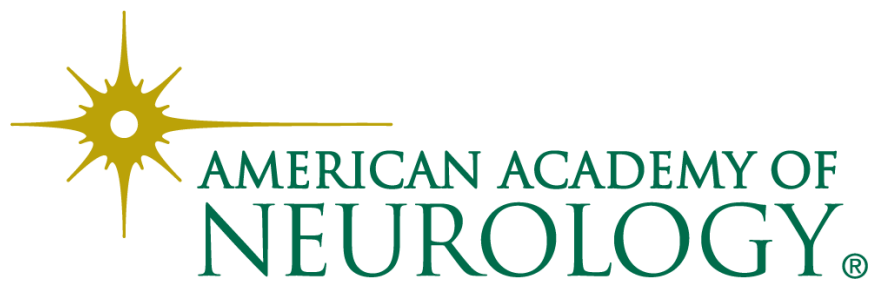

